NOTE

\title{
Feeding by the heterotrophic dinoflagellate Protoperidinium bipes on the diatom Skeletonema costatum
}

\author{
Hae Jin Jeong ${ }^{1, *}$, Yeong Du Yoo ${ }^{2}$, Seong Taek Kim ${ }^{2}$, Nam Seon Kang ${ }^{2}$
}

${ }^{1}$ School of Earth and Environmental Science, College of Natural Sciences, Seoul National University, Seoul 151-747, RO Korea ${ }^{2}$ Department of Oceanography, Kunsan National University, San 68, Miryong-dong, Kunsan 573-701, RO Korea

\begin{abstract}
The heterotrophic dinoflagellate Protoperidinium bipes is a predominant heterotrophic dinoflagellate (maximum density $=137$ cells $\mathrm{ml}^{-1}$ ) during diatom blooms. To investigate its role as a grazer in the population dynamics of diatoms, we measured growth and ingestion rates of $P$. bipes when feeding on the common diatom Skeletonema costatum. We also calculated grazing coefficients by combining field data on abundances of $P$. bipes and co-occurring $S$. costatum with laboratory data on ingestion rates obtained in the present study. Specific growth rates of $P$. bipes increased continuously with increasing concentration of $S$. costatum. The maximum specific growth rate of $P$. bipes on $S$. costatum was $1.37 \mathrm{~d}^{-1}$ when data for the growth rate were fitted to a Michaelis-Menten equation. The threshold prey concentration (where net growth $=0$ ) was $111 \mathrm{ng} \mathrm{C} \mathrm{ml}^{-1}\left(4270 \mathrm{cells} \mathrm{m}^{-1}\right)$. Maximum ingestion and clearance rates of $P$. bipes on this diatom were $2.9 \mathrm{ng} \mathrm{C}$ grazer $^{-1} \mathrm{~d}^{-1}\left(112\right.$ cells grazer $\left.^{-1} \mathrm{~d}^{-1}\right)$ and $1.0 \mu \mathrm{l}$ grazer ${ }^{-1} \mathrm{~h}^{-1}$, respectively. $P$. bipes exhibited the highest maximum swimming speed (ca. $8.3 \mathrm{~mm} \mathrm{~s}^{-1}$ ) and maximum volume-specific clearance rate $\left(5.4 \times 10^{6} \mathrm{~h}^{-1}\right)$ among Protoperidinium species so far reported. Calculated grazing coefficients by $P$. bipes on $S$. costatum $\left(0.001\right.$ to $0.034 \mathrm{~h}^{-1}$, i.e. 0.1 to $3.4 \%$ of $S$. costatum populations were removed by a $P$. bipes population in $1 \mathrm{~h}$ ) were much higher than those by cooccurring Acartia spp. $\left(<0.002 \mathrm{~h}^{-1}\right)$. The results of the present study suggest that $P$. bipes sometimes has a considerable grazing impact on populations of $S$. costatum.
\end{abstract}

KEY WORDS: Algal bloom · Growth · Grazing · Impact · Ingestion · Protist · Arcartia · Copepod

\section{INTRODUCTION}

Marine diatoms and heterotrophic protists are the major components of marine plankton communities. The abundance of heterotrophic protists often increases in the decline stage of diatom blooms (Kristiansen et al. 2001) and ingestion of diatom cells by heterotrophic protists has been observed (Jacobson \& Anderson 1986, 1993, Hansen 1992, Strom \& Buskey 1993, Buskey et al. 1994, Naustvoll 1998, Skovgaard \& Hansen 2003). Thus, it has been suggested that graz- ing pressure by heterotrophic protists may sometimes play an important role in the population dynamics of diatoms (Jacobson \& Anderson 1993).

Skeletonema costatum commonly dominates diatom abundance in coastal waters (Pratt 1965, Durbin \& Durbin 1981, Reid et al. 1985, Marshall \& Ranasinghe 1989, Ramaiah \& Furuya 2002, Balkis 2003). While there are many studies on feeding by copepods on this diatom (i.e. Conover 1956, Martin 1965, Paffenhöfer 1976, Deason 1980), there are few studies on the growth of heterotrophic protists that graze on $S$. costa- 
tum (Hansen 1992), and no reports on ingestion rate and grazing impact. To understand the population dynamics of $S$. costatum and the total grazing pressure exerted by zooplankton on $S$. costatum, the grazing impact by co-occurring dominant heterotrophic protists on $S$. costatum should be explored.

The heterotrophic dinoflagellate Protoperidinium bipes is often abundant (reported maximum density = 137 cells $\mathrm{ml}^{-1}$ ) in coastal waters when Skeletonema costatum is abundant (Jeong et al. 2000, Balkis 2003, Roberts et al. 2003). It has a wide distribution (Lessard \& Swift 1986, Jacobson 1987, Nielsen et al. 1993, Bralewska \& Witek 1995, Tiselius \& Kuylendstierna 1996, Caroppo 2000, Tuschling et al. 2000, Johnson \& Costello 2002, Lovejoy et al. 2002, Roberts et al. 2003), but its feeding habit is as yet unknown.

We established a monoclonal culture of Protoperidinium bipes and conducted experiments to examine its numerical and functional responses when grazing on Skeletonema costatum and measured its swimming speed. We also estimated grazing coefficients attributable to $P$. bipes on $S$. costatum using our data for ingestion rates obtained from the laboratory experiments and the abundances of predator and prey in the field. The results of the present study provide a basis for understanding the potential of $P$. bipes to influence the population dynamics of $S$. costatum.

\section{MATERIALS AND METHODS}

Culture of diatom prey. Skeletonema costatum, isolated from a coastal water off Kwangyang, Korea, were grown at $20^{\circ} \mathrm{C}$ in enriched $\mathrm{f} / 2$ seawater media (Guillard \& Ryther 1962), under continuous illumination of $100 \mu \mathrm{E} \mathrm{m} \mathrm{m}^{-2} \mathrm{~s}^{-1}$ provided by cool white fluorescent lights. Only cultures in an exponential growth phase were used for the feeding experiments. The carbon content for $S$. costatum $\left(0.026 \mathrm{ng} \mathrm{C}\right.$ cell $\left.^{-1}\right)$ was estimated from cell volume $\left(250 \mu^{3}\right)$ according to MendenDeuer \& Lessard (2000).

Isolation and culture of Protoperidinium bipes. A $40 \mathrm{~cm}$ diameter, $20 \mu \mathrm{m}$ mesh plankton net was used to collect samples from a coastal water off Kwangyang, Korea, during October 2003 when the water temperature and salinity were $17.6^{\circ} \mathrm{C}$ and $30.6 \mathrm{psu}$, respectively. The samples were screened gently through a $154 \mu \mathrm{m}$ Nitex mesh and placed in 11 polycarbonate (PC) bottles. The bottles were spiked with $50 \mathrm{ml}$ of $\mathrm{f} / 2$ media, and Skeletonema costatum (density $=$ ca. 40000 cells $\mathrm{ml}^{-1}$ ) were added as food. The bottles were placed on plankton wheels rotating at $0.9 \mathrm{rpm}$ and incubated at $20^{\circ} \mathrm{C}$ under the continuous illumination of $20 \mu \mathrm{E} \mathrm{m}{ }^{-2}$ $\mathrm{s}^{-1}$ of cool white fluorescent light. A week later, aliquots of the enriched water were transferred to 6-well tissue culture plates and a monoclonal culture of Protoperidinium bipes was established by 2 serial single cell isolations. Once dense cultures of $P$. bipes were obtained, they were transferred to 270 or $500 \mathrm{ml}$ PC bottles of fresh $S$. costatum prey (density = ca. 50000 cells $\mathrm{ml}^{-1}$ ) every $3 \mathrm{~d}$. Experiments were conducted when a large volume of $P$. bipes culture was available.

Cell volume. Cell length and maximum width of Protoperidinium bipes preserved in 5\% acid Logol's solution were measured using a compound or inverted microscope at the beginning of the experiment and the end of each interval ( $\mathrm{n}=20$ for each prey concentration). The shape of $P$. bipes was estimated to be 2 small cones ( 2 cones connected to each other in the bottom half of the cell: W shape) connected to a large cone (top half of the cell: $\Lambda$ shape) at the cell equator (= maximum width of the cell). Cell volume of the preserved $P$. bipes was calculated according to the equation: volume $=1 / 3 \times\left[\pi(\text { cell width } / 2)^{2}\right] \times[$ cell length $/ 2]+2 \times\{1 / 3$ $\left.\times[\pi \text { (cell width } / 4)^{2}\right] \times[$ cell length $\left./ 2]\right\}$.

The carbon content for Protoperidinium bipes was estimated from cell volume according to MendenDeuer \& Lessard (2000).

Swimming speed. Swimming speeds of Protoperidinium bipes starved for 12 to $24 \mathrm{~h}$ were measured at $20^{\circ} \mathrm{C}$ using a video analyzing system. For each species, aliquots from a dense culture were added to multi-well plates and allowed to acclimate for $30 \mathrm{~min}$. The video camera focused on 1 well (i.e. seen as 1 circle) in a multi-well plate and then swimming dinoflagellates were recorded at $40 \times$ magnification. The mean and maximum swimming velocities were analyzed for all swimming cells seen for the first $15 \mathrm{~min}$. Average swimming speed was calculated based on the linear displacement of cells in $1 \mathrm{~s}$ during single-frame playback. Swimming speeds of 45 cells were measured.

Growth and ingestion rates. Experiments were designed to measure growth, ingestion, and clearance rates of Protoperidinium bipes, as a function of the prey concentration, when feeding on Skeletonema costatum.

Two days before these experiments were conducted, dense cultures of Protoperidinium bipes grazing on Skeletonema costatum were transferred into a 11 PC bottle containing low concentrations of the target prey (ca. 5000 cells ml ${ }^{-1}$ ). This was done to acclimate the predator to the target prey and minimize any possible residual growth resulting from the ingestion of prey during batch culture. The bottle was filled to capacity with filtered seawater and placed on a plankton wheel to incubate as above. A $10 \mathrm{ml}$ aliquot was removed from the bottle and fixed with $5 \%$ Lugol's solution. The abundances of $P$. bipes and its prey were determined by enumerating cells in three $1 \mathrm{ml}$ Sedgwick-Rafter counting chambers (SRCs). 
Initial concentrations (cells $\mathrm{ml}^{-1}$ ) of Protoperidinium bipes and the target prey were established using an autopipette to deliver predetermined volumes of known cell concentrations to the bottles. Triplicate $80 \mathrm{ml}$ PC experiment bottles (mixtures of predator and prey) and triplicate control bottles (prey only) were set up at each predator-prey combination. Triplicate control bottles containing only $P$. bipes were also established at 1 predator concentration. Five $\mathrm{ml}$ of $\mathrm{f} / 2$ medium was added to all the bottles, which were then filled to capacity with freshly filtered seawater and capped. To determine the actual mean predator and prey densities (cells $\mathrm{ml}^{-1}$ ) at the beginning of the experiment (6/94, 9/516, 11/990, 16/4997, 23/10590, 34/45240, 50/ $72150,78 / 0$ ) and after 24,48 , and $72 \mathrm{~h}$ incubation, $8 \mathrm{ml}$ aliquots were removed from each bottle and fixed with $5 \%$ Lugol's solution, and all $P$. bipes cells and all or $>200$ prey cells in the three $1 \mathrm{ml}$ SRCs were enumerated. Prior to taking subsamples, the condition of $P$. bipes and its prey was assessed under a dissecting microscope. The bottles were filled again to capacity with freshly filtered seawater, capped, and placed on the plankton wheel under the environmental conditions described above. The dilution of the cultures associated with refilling the bottles was taken into consideration in calculating growth and ingestion rates.

The specific growth rate of Protoperidinium bipes $(\mu$, $\mathrm{d}^{-1}$ ) was calculated by averaging the instantaneous growth rates (IGR) for each sampling interval, calculated as:

$$
\mathrm{IGR}=\frac{\ln \left(S_{t_{2}} / S_{t_{1}}\right)}{t_{2}-t_{1}} \times 24
$$

where $S_{t 1}$ and $S_{t 2}=$ the concentration of $P$. bipes at consecutive samplings. The final $t_{2}$ for calculation was $48 \mathrm{~h}$, which provided the highest specific growth rate. Mean prey concentrations for $48 \mathrm{~h}$ were also calculated by averaging the instantaneous mean prey concentrations at 0 to $24 \mathrm{~h}$ and at 24 to $48 \mathrm{~h}$. The instantaneous mean prey concentration for each sampling interval was calculated using the equations of Frost (1972).

Data for Protoperidinium bipes growth rate were fitted to a Michaelis-Menten equation:

$$
\mu=\frac{\mu_{\max }\left(x-x^{\prime}\right)}{K_{\mathrm{GR}}+\left(x-x^{\prime}\right)}
$$

where $\mu_{\max }=$ the maximum growth rate $\left(\mathrm{d}^{-1}\right) ; x=$ prey concentration (cells $\mathrm{ml}^{-1}$ or $\mathrm{ng} \mathrm{C} \mathrm{ml}^{-1}$ ), $\mathrm{x}^{\prime}=$ threshold prey concentration (the prey concentration where $\mu=$ $0)$, and $K_{\mathrm{GR}}=$ the prey concentration sustaining $1 / 2 \mu_{\max }$. Data were iteratively fitted to the model using DeltaGraph $^{\circledR}$ (Delta Point).
Ingestion and clearance rates were calculated using the equations of Frost (1972) and Heinbokel (1978). The incubation time for calculating ingestion and clearance rates was the same as for estimating growth rate. Ingestion rate (IR) data were fitted to a MichaelisMenten equation:

$$
\mathrm{IR}=\frac{I_{\max }(x)}{K_{\mathrm{IR}}+(x)}
$$

where $I_{\max }=$ the maximum ingestion rate (cells grazer $^{-1} \mathrm{~d}^{-1}$ or ng $C$ grazer $\left.{ }^{-1} \mathrm{~d}^{-1}\right) ; x=$ prey concentration

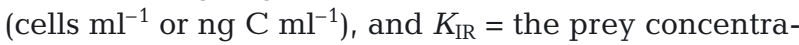
tion sustaining $1 / 2 I_{\max }$

Gross growth efficiency. Gross growth efficiency (GGE), defined as grazer biomass produced (+) or lost $(-)$ per prey biomass ingested, as a function of mean prey concentration, was calculated from estimates of carbon content per cell based on cell volume at each mean prey concentration.

Grazing impact. With some assumptions (see Table 1), we estimated grazing coefficients attributable to Protoperidinium bipes feeding on Skeletonema costatum by combining field data on abundances of the grazer and the prey with ingestion rates of the grazer on the prey obtained in the present study. For comparison (of the grazing coefficients between $P$. bipes and Acartia spp. on $S$. costatum), we also estimated grazing coefficients attributable to co-occurring dominant copepods Acartia spp. feeding on $S$. costatum by combining field data on abundances of Acartia spp. and $S$. costatum with ingestion rates of the grazer on the prey obtained from the Michaelis-Menten equation in Fig. 4 of Deason (1980). The data on the abundances of S. costatum, $P$. bipes, and co-occurring Acartia spp. used in this estimation were obtained from water samples and nettowed samples collected from the coastal waters at the same stations off Kwangyang (1999-2001), Koheung (1997-1999), and Saemankeum (1999), Korea.

Grazing coefficients $\left(g, \mathrm{~h}^{-1}\right)$ were calculated as:

$$
g=(1 / \Delta t)\left\{\ln \left[C_{\mathrm{i}} /\left(C_{\mathrm{i}}-C_{\mathrm{e}}\right)\right]\right\}
$$

where $\Delta t(\mathrm{~h})$ is a time interval, $C_{\mathrm{e}}\left(\right.$ cells $\left.\mathrm{ml}^{-1}\right)$ is the number of prey cells eaten by the Protoperidinium bipes or Acartia spp. population in $1 \mathrm{ml}$ of seawater in $1 \mathrm{~h}$, and $C_{\mathrm{i}}$ (cells $\mathrm{ml}^{-1}$ ) is the initial prey cell concentration in a given hour. The values of $C_{\mathrm{e}}$ were calculated as:

$$
C_{\mathrm{e}}=\mathrm{PIR} \times 1 \mathrm{~h}=\mathrm{IR} \times G \times 1 \mathrm{~h}
$$

where PIR is the population ingestion rate of $P$. bipes or Acartia spp. feeding on $S$. costatum in $1 \mathrm{ml}$ of seawater (prey eaten $\mathrm{ml}^{-1} \mathrm{~h}^{-1}$ ), IR is the ingestion rate (prey eaten grazer $^{-1} \mathrm{~h}^{-1}$ ) of $P$. bipes or Acartia spp. feeding on $S$. costatum, and $G$ is the abundance (cells $\mathrm{ml}^{-1}$ ) of $P$. bipes or Acartia spp. at the same time as $C_{\mathrm{i}}$. 


\section{RESULTS}

\section{Swimming speed}

The average $( \pm \mathrm{SE}, \mathrm{n}=45)$ and maximum swimming speeds of Protoperidinium bipes starved for 12 to $24 \mathrm{~h}$ were $4006( \pm 306)$ and $8269 \mu \mathrm{m} \mathrm{s}^{-1}$, respectively. It was difficult to capture actively swimming $P$. bipes cells using a micropipette under a dissecting microscope.

\section{Growth rates}

The specific growth rates of Protoperidinium bipes feeding on a unialgal diet of Skeletonema costatum increased continuously with increasing mean prey concentration (Fig. 1). When the data were fitted to Eq. (2), the maximum specific growth rates $\left(\mu_{\max }\right)$ of P. bipes were $1.37 \mathrm{~d}^{-1}$. Threshold prey concentrations (where net growth $=0$ ) were $111 \mathrm{ng} \mathrm{C} \mathrm{ml}^{-1}$ (4270 cells $\mathrm{ml}^{-1}$ ).

\section{Ingestion and clearance rates}

The ingestion rates of Protoperidinium bipes feeding on unialgal diets of Skeletonema costatum increased

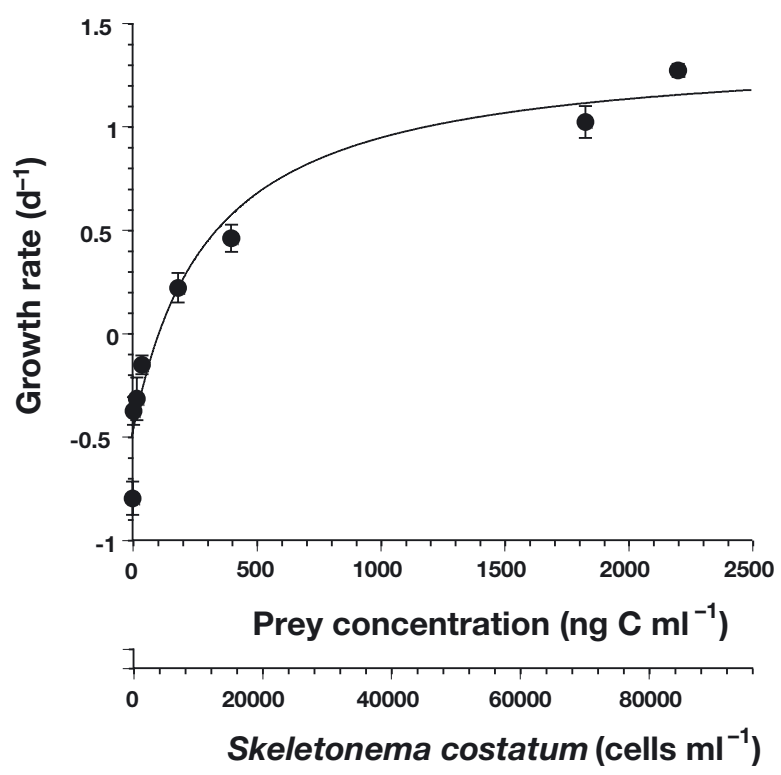

Fig. 1. Specific growth rates of Protoperidinium bipes feeding on Skeletonema costatum as a function of mean prey concentration $\left(x, \mathrm{ng} \mathrm{C} \mathrm{ml}^{-1}\right)$. Growth rates were calculated by averaging the instantaneous growth rates for 0 to $24 \mathrm{~h}$ and for 24 to $48 \mathrm{~h}$. Symbols represent treatment means $\pm 1 \mathrm{SE}$. Curves are fitted by a Michaelis-Menten equation (Eq. 2) using all treatments in the experiment. Growth rate $\left(G R, d^{-1}\right)$ $=1.37\{(x-111) /[412+(x-111)]\}, \mathrm{r}^{2}=0.937$

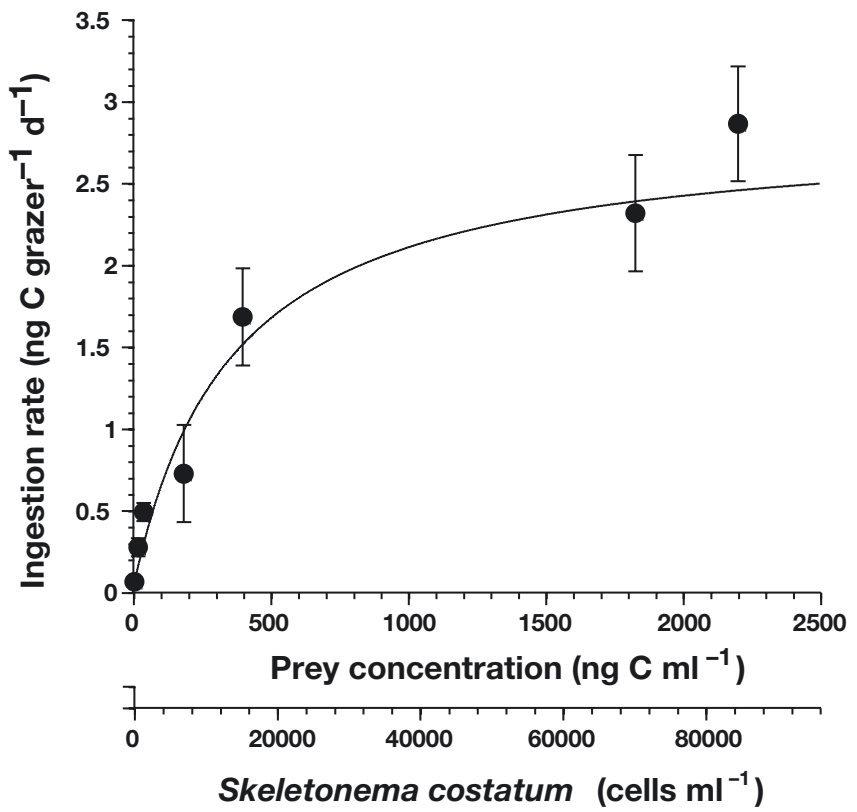

Fig. 2. Ingestion rates of Protoperidinium bipes feeding on Skeletonema costatum as a function of mean prey concentration $\left(x, \mathrm{ng} \mathrm{C} \mathrm{ml}^{-1}\right)$. Ingestion rates were calculated by averaging the instantaneous ingestion rates for 0 to $24 \mathrm{~h}$ and for 24 to $48 \mathrm{~h}$. Symbols represent treatment means \pm 1 SE. Curves are fitted by a Michaelis-Menten equation (Eq. 3) using all treatments in the experiment. Ingestion rate (IR, ng C grazer ${ }^{-1} \mathrm{~d}^{-1}$ ) $=2.9[x /(355+x)], r^{2}=0.794$

rapidly with increasing mean prey concentration below ca. $350 \mathrm{ng} \mathrm{C} \mathrm{ml}^{-1}$ (13 460 cells ml$^{-1}$ ) and slowly, but continuously, increased at higher prey concentrations (Fig. 2). When the data were fitted to Eq. (3), the maximum ingestion rate of $P$. bipes was $2.9 \mathrm{ng} \mathrm{C}$ grazer $^{-1} \mathrm{~d}^{-1}\left(112\right.$ cells grazer $\left.{ }^{-1} \mathrm{~d}^{-1}\right)$.

The maximum clearance rate of Protoperidinium bipes was $1.0 \mu$ grazer $^{-1} \mathrm{~h}^{-1}$, which was measured at the lowest prey concentration. The maximum volumespecific clearance rate was $5.4 \times 10^{6} \mathrm{~h}^{-1}\left(1.0 \mu\right.$ grazer $^{-1}$ $\mathrm{h}^{-1}$ with a volume of $184 \mathrm{\mu m}^{3}$ ).

\section{Cell volume}

Cell volume of Protoperidinium bipes fed Skeletonema costatum after $48 \mathrm{~h}$ incubation did not change markedly with increasing mean prey concentrations between 3 and $17 \mathrm{ng} \mathrm{C} \mathrm{ml}^{-1}$ (130 to $180 \mu^{3}$ ), but it increased rapidly up to $1160 \mu^{3}$ at mean prey concentrations between 17 and $183 \mathrm{ng} \mathrm{C} \mathrm{ml}^{-1}$ and slowly at higher prey concentrations, reaching a maximum of $1430 \mu^{3}$ at a prey concentration of $1826 \mathrm{ng} \mathrm{C} \mathrm{ml}^{-1}$ (Fig. 3). The cell volume of $P$. bipes without added prey for $48 \mathrm{~h}$ was $126 \mu^{3}$. 


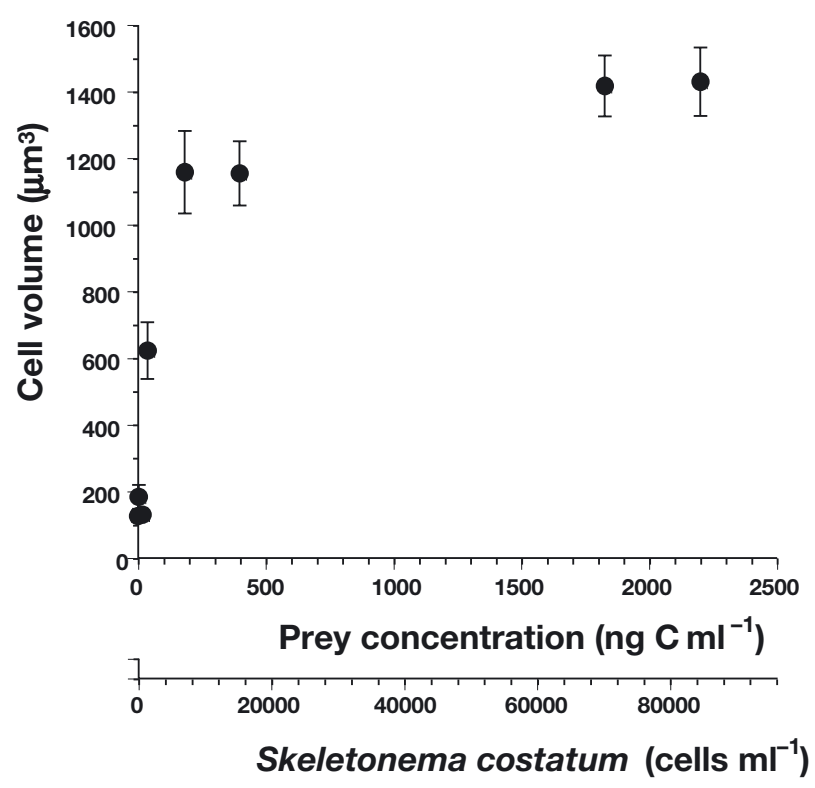

Fig. 3. Cell volume of Protoperidinium bipes feeding on Skeletonema costatum as a function of mean prey concentration. Symbols represent treatment means \pm 1 SE. $N=20$ for each prey concentration

\section{Gross growth efficiency}

GGE of Protoperidinium bipes feeding on Skeletonema costatum were negative at mean prey concentrations $\leq 37 \mathrm{ng} \mathrm{C} \mathrm{ml}^{-1}\left(1420\right.$ cells $\left.\mathrm{ml}^{-1}\right)$, and they increased linearly up to $20 \%$ with increasing mean prey concentration (Fig. 4).

\section{Grazing impact}

Grazing coefficients $(g)$ attributable to Protoperidinium bipes feeding on co-occurring Skeletonema costatum were 0.001 to $0.034 \mathrm{~h}^{-1}$ (Fig. 5A, Table 1). In general $g$ increased with increasing $P$. bipes concentration. $g$ attributable to Acartia spp. feeding on S. costatum were $<0.002 \mathrm{~h}^{-1}$ (Fig. 5B, Table 1).

\section{DISCUSSION}

\section{Protistan predators on Skeletonema costatum}

While many metazoan grazers on Skeletonema costatum have been reported (Conover 1956, Martin 1965, Paffenhöfer 1976, Deason 1980, Jordana et al. 2001), until now few heterotrophic protists have been known, e.g. Protoperidinium spinulosum (Jacobson \& Anderson 1986), Diplopsalis lenticula (Naustvoll 1998), and P. pellucidum (Hansen 1992) are known to feed on $S$. costatum. P. huberi is also able to feed on unknown Skeletonema species (cell volume of Skeletonema sp. $=200 \mu^{3}$ ) (Buskey et al. 1994). However, these studies on the heterotrophic protists have not measured growth and grazing rates of the grazers on $S$. costatum as a function of the prey concentration and there have been few studies to quantify grazing impact by the grazers on the prey. Based on the field data showing that $P$. bipes was abundant when $S$. costatum was abundant in most Korean coastal waters (Jeong et al. 2000, 2002, Yoo et al. 2002), it has been suggested that $S$. costatum (and possibly other co-occurring diatoms) might support the rapid growth of $P$. bipes when the concentration of the diatoms is high.

\section{Swimming speed}

Protoperidinium bipes has much higher average and maximum swimming speeds (4006 and $8269 \mu \mathrm{m} \mathrm{s}^{-1}$ ) than any Protoperidinium species so far reported (see Table 2); $P$. cf. quinquecorne has a swimming speed of $1500 \mu \mathrm{m} \mathrm{s}^{-1}$ and $P$. subinerme, P. ovatum, P. claudicans, and P. crassipes have swimming speeds of 100 to $310 \mu \mathrm{m} \mathrm{s}^{-1}$ (Peters 1929 cited by Levandowsky \& Kaneta 1987). Data from these previous studies and this study show that the swimming speeds of Protoperidinium spp. are not correlated with their cell volume. This relationship suggests that

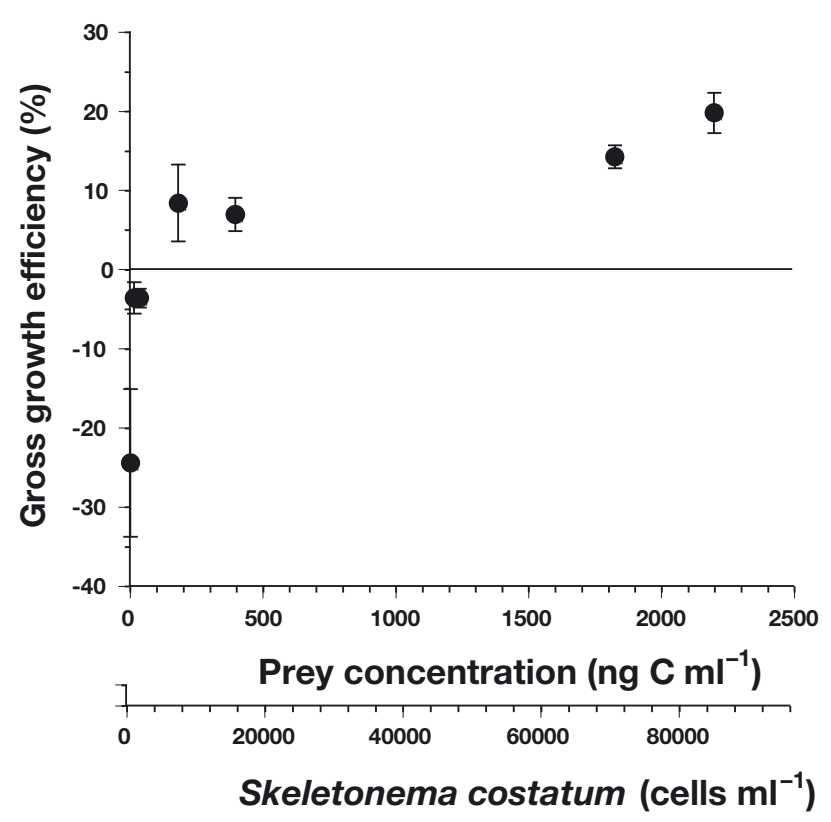

Fig. 4. Gross growth efficiency, defined as Protoperidinium bipes biomass produced (+) or lost (-) per Skeletonema costatum biomass ingested, as a function of mean prey concentration 

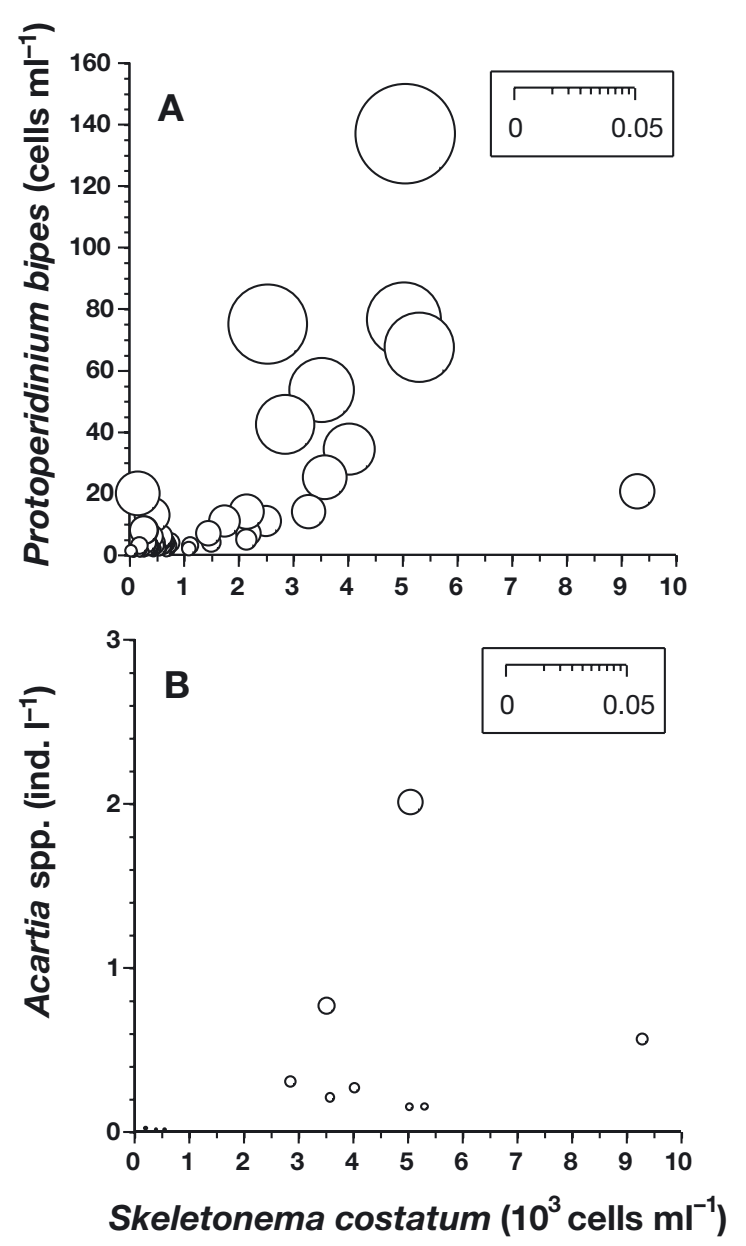

Fig. 5. Calculated grazing coefficients $\left(g, \mathrm{~h}^{-1}\right)$ attributable to (A) Protoperidinium bipes and (B) Acartia spp. feeding on Skeletonema costatum (see text for calculation). $\mathrm{N}=60$

factors other than prey cell volume, such as cell shape, may have a marked effect on the swimming speed of Protoperidinium spp.; $P$. bipes has an elongated shape (ratio of cell length relative to cell width $=$ ca. 1.5), while $P$. cf. quinquecorne, $P$. subinerme, $P$. ovatum, $P$. claudicans, and $P$. crassipes have almost spherical shapes (ratios = 0.80 to 1.0$)$. The extremely high swimming speed of $P$. bipes may provide a high encounter rate between this grazer and its prey, particularly at low prey concentrations, but causes great energy loss (Crawford 1992).

\section{Growth}

The maximum growth rate $(\mu)$ of Protoperidinium bipes on Skeletonema costatum $\left(1.37 \mathrm{~d}^{-1}\right)$ is the highest among the rates of the Protoperidinium species so far reported (see Table 2); $P$. hirobis had a maximum growth rate of $1.23 \mathrm{~d}^{-1}$ when feeding on the diatom Leptocylindrus danicus (Jacobson \& Anderson 1986). The high growth rate of $P$. bipes might enable it to be abundant during diatom blooms in nature (our field data).

There are a few reports on the growth rates of other heterotrophic protists feeding on Skeletonema costatum, and this diatom has been known not to be the optimal prey for these grazers; Gyrodinium dominans has a maximum growth rate of $0.25 \mathrm{~d}^{-1}$ when fed $S$. costatum, while its highest maximum growth rate of $0.54 \mathrm{~d}^{-1}$ was observed when fed the dinoflagellate Heterocapsa triquetra (Nakamura et al. 1995), when corrected to $20^{\circ} \mathrm{C}$ using $Q_{10}=2.8$ (Hansen et al. 1997). Protoperidinium pellucidum has a maximum growth rate of $0.55 \mathrm{~d}^{-1}$ when fed $S$. costatum (Hansen 1992), while its highest maximum growth rate of ca. $0.7 \mathrm{~d}^{-1}$ was observed when fed the diatoms Ditylum brightwellii or Thalassiosira sp. (Buskey 1997). Therefore, $P$. bipes exhibited the highest growth rate among heterotrophic protistan grazers of $S$. costatum.

Positive growth rates of Protoperidinium bipes feeding on Skeletonema costatum were maintained at mean prey concentrations $>111 \mathrm{ng} \mathrm{C} \mathrm{ml}^{-1}$, which was much higher than those of $P$. huberi feeding on Ditylum brightwelli (>10 $\mathrm{ng} \mathrm{C} \mathrm{ml}{ }^{-1}$ ) (Buskey et al. 1994), Diplopsalis lenticula on D. brightwelli (24 $\mathrm{ng} \mathrm{C} \mathrm{ml}^{-1}$ ) (Naustvoll 1998), or another pallium feeder, Oblea rotunda, on $D$. brightwelli (>10 $\mathrm{ng} \mathrm{C} \mathrm{ml}^{-1}$ ) (Strom \& Buskey 1993). Energy loss due to the high swimming speed of small $P$. bipes might cause negative growth at low prey concentrations.

\section{Ingestion and clearance}

There have been no reports on ingestion and clearance rates of heterotrophic protists feeding on Skeletonema costatum, while there are many studies on those of copepods feeding on this diatom.

The maximum ingestion rate $\left(I_{\max }\right)$ of Protoperidinium bipes grazing on Skeletonema costatum obtained in this study (2.9 ng C grazer $\left.{ }^{-1} \mathrm{~d}^{-1}\right)$ was higher than that of $P$. hirobis grazing on Leptocylindrus danicus (0.8), but lower than that for other Protoperidinium species on phytoplankton so far reported (5.9 to 17.8), when corrected to $20^{\circ} \mathrm{C}$ using $Q_{10}=2.8$ (Hansen et al. 1997) (Table 2). However, the ratios of $I_{\max }$ of $P$. bipes on $S$. costatum relative to cell volume were 6 to 15 times higher than those for other Protoperidinium species so far reported.

The maximum clearance rate $\left(C_{\max }\right)$ of Protoperidinium bipes grazing on Skeletonema costatum obtained in this study $\left(1.0 \mu\right.$ grazer $\left.^{-1} \mathrm{~d}^{-1}\right)$ is higher than that of Protoperidinium cf. divergens (0.7) and P. crassipes (0.5) grazing on Gonyaulax polyedra (= presently Lingulodinium polyedrum), P. hirobis on Leptocylindrus danicus (0.5) and the pallium feeder Oblea rotunda on Ditylum brightwellii (0.7), when corrected 
Table 1. Estimation of grazing impact by a Protoperidinium bipes population or Acartia spp. populations feeding on a Skeletonema costatum population using Eq. (3) of this study and the Michaelis-Menten equation in Fig. 4 of Deason (1980), and the abundances of co-occurring S. costatum, P. bipes, and Acartia spp. obtained from the water samples collected off Kwangyang, Korea in 2001. PPIR $=P$. bipes's population ingestion rate; $\mathrm{Pg}=P$. bipes's grazing coefficient $\left(\mathrm{h}^{-1}\right)$, APIR $=A$ cartia spp.'s population ingestion rate; $\mathrm{Ag}=$ Acartia spp.'s grazing coefficient $\left(\mathrm{h}^{-1}\right)$

\begin{tabular}{|c|c|c|c|c|c|c|}
\hline $\begin{array}{l}\text { S. costatum } \\
\text { concentration } \\
\left(\text { cells ml } \mathrm{m}^{-1}\right)\end{array}$ & $\begin{array}{c}P . \text { bipes } \\
\text { concentration } \\
\left(\text { cells ml } \mathrm{m}^{-1}\right)\end{array}$ & $\begin{array}{c}\text { PPIR } \\
\text { (prey eaten } \\
\mathrm{ml}^{-1} \mathrm{~h}^{-1} \text { ) }\end{array}$ & $\begin{array}{c}\mathrm{Pg} \\
\left(\mathrm{h}^{-1}\right)\end{array}$ & $\begin{array}{c}\text { Acartia spp. } \\
\text { density } \\
\left(\text { ind. } \mathrm{l}^{-1}\right)\end{array}$ & $\begin{array}{c}\text { APIR }^{\mathrm{a}} \\
\text { (prey eaten } \\
\mathrm{ml}^{-1} \mathrm{~h}^{-1} \text { ) }\end{array}$ & $\begin{array}{c}\mathrm{Ag} \\
\left(\mathrm{h}^{-1}\right)\end{array}$ \\
\hline 417 & 30 & 2 & 0.004 & 0.0037 & 0 & 0 \\
\hline 2533 & 75 & 54 & 0.021 & 0.0002 & 0 & 0 \\
\hline 2852 & 42 & 33 & 0.012 & 0.3062 & 1 & 0.0004 \\
\hline 3520 & 54 & 50 & 0.014 & 0.7674 & 1 & 0.0002 \\
\hline 3576 & 25 & 24 & 0.007 & 0.2088 & 3 & 0.0009 \\
\hline 4022 & 34 & 36 & 0.009 & 0.2672 & 1 & 0.0003 \\
\hline 5028 & 76 & 94 & 0.019 & 0.1531 & 1 & 0.0002 \\
\hline 5049 & 137 & 169 & 0.034 & 2.0095 & 10 & 0.0021 \\
\hline 5303 & 68 & 86 & 0.016 & 0.1531 & 1 & 0.0002 \\
\hline 9290 & 21 & 38 & 0.004 & 0.5653 & 4 & 0.0004 \\
\hline
\end{tabular}

assuming that the ingestion rate of Acartia omorii, the dominant copepod in the water samples collected off Kwangyang, on Skeletonema cosatum is the same as that of $A$. hudsonica obtained by Deason (1980) because the size of A. omorii is similar to that of A. hudsonica

Table 2. Comparison of growth, ingestion and clearance rates in the genus Protoperidinium. Rates are corrected to $20^{\circ} \mathrm{C}$ using $Q_{10}=2.8$ (Hansen et al. 1997). PDV: predator volume $\left(10^{3} \times \mu \mathrm{m}^{3}\right)_{\text {; }}$ DIA: diatom; DN: dinoflagellate; PYV: prey volume $\left(10^{3} \times \mu \mathrm{m}^{3}\right)$; $\mu_{\max }$ : maximum growth rate $\left(\mathrm{d}^{-1}\right) ; I_{\max }$ : maximum ingestion rate $\left(\mathrm{ng} \mathrm{C} \mathrm{grazer}^{-1} \mathrm{~d}^{-1}\right) ; C_{\max }$ : maximum clearance rate $\left(\mu l\right.$ grazer $^{-1}$ $\left.\mathrm{h}^{-1}\right) ; \mathrm{SC}_{\max }$ : maximum volume-specific clearance rate $\left(10^{5} \mathrm{~h}^{-1}\right) ; \mathrm{GGE}_{\max }$ : maximum gross growth efficiency $(\%) ; \mathrm{SS}_{\max }$ : maximum swimming speed $\left(\mathrm{mm} \mathrm{s}^{-1}\right)$

\begin{tabular}{|c|c|c|c|c|c|c|c|c|c|c|}
\hline Predator & PDV & Prey & PYV & $\mu_{\max }$ & $I_{\max }$ & $C_{\max }$ & $\mathrm{SC}_{\max }$ & $\mathrm{GGE}_{\max }$ & $\mathrm{SS}_{\max }$ & Source $^{\mathrm{a}}$ \\
\hline P. bipes & 1 & Skeletonema costatum (DIA) & 0.25 & 1.37 & 2.9 & 1.0 & 54 & 20 & 8.3 & This study \\
\hline P. hirobis & 4 & Leptocylindrus danicus (DIA) & 0.35 & 1.23 & 0.8 & 0.5 & 1.2 & 40 & $0.3^{\mathrm{a}}$ & $\begin{array}{l}\text { Jacobson \& Anderson } \\
\text { (1993) }\end{array}$ \\
\hline P. pellucidum & 25 & Skeletonema costatum (DIA) & 0.25 & 0.55 & & & & & & Hansen (1992) \\
\hline P. pellucidum & 25 & Thalassiosira sp. 1 (DIA) & 3.6 & 0.7 & & & & & & Buskey (1997) \\
\hline P. pellucidum & 25 & Ditylum brightwellii (DIA) & 9.7 & 0.7 & 11.5 & & & & 0.6 & Buskey (1997) \\
\hline P. pellucidum & 25 & Prorocentrum micans (DN) & 18.4 & 0.4 & 7.7 & & & & & Buskey (1997) \\
\hline P. pellucidum & 25 & Gonyaulax polyedra (DN) & 17.0 & 0.4 & & & & & & Buskey (1997) \\
\hline P. huberi & 39 & Ditylum brightwellii (DIA) & 9.7 & 0.72 & 17.8 & 23 & 5.9 & 59 & & Buskey et al. (1994) \\
\hline P. cf. divergens & 119 & Gymnodinium sanguineum (DN) & 25.0 & 0.28 & & & & & & Jeong \& Latz (1994) \\
\hline P. cf. divergens & 119 & Gonyaulax polyedra (DN) & 28.5 & 0.53 & 13.3 & 0.74 & 0.088 & 41 & 1.4 & Jeong \& Latz (1994) \\
\hline P. crassipes & 204 & Gymnodinium sanguineum (DN) & 25.0 & 0.12 & & & & & & Jeong \& Latz (1994) \\
\hline P. crassipes & 204 & Gonyaulax polyedra (DN) & 28.5 & 0.34 & 5.9 & 0.52 & 0.025 & 47 & & Jeong \& Latz (1994) \\
\hline
\end{tabular}

to $20^{\circ} \mathrm{C}$ using $Q_{10}=2.8$ (Hansen et al. 1997) (Table 2). However, it was lower than that of $P$. huberi grazing on Ditylum brightwellii (23) or another pallium feeder, Diplopsalis lenticula (4.5) (Buskey et al. 1994, Naustvoll 1998). The high swimming speed of $P$. bipes might increase the encounter rate between this grazer and its prey and thus enable this grazer to capture a prey cell at low prey concentrations.
The maximum volume-specific clearance rate of Protoperidinium bipes feeding on Skeletonema costatum obtained in this study $\left(5.4 \times 10^{6} \mathrm{~h}^{-1}\right)$ was higher than that of any other heterotrophic protists so far reported (Hansen et al. 1997). A high maximum clearance rate of $P$. bipes with a small volume $\left(184 \mu^{3}\right)$ may account for this very high maximum volume-specific clearance rate. 


\section{Gross growth efficiency}

Maximum GGE of Protoperidinium bipes feeding on Skeletonema costatum (20\%) is lower than P. hirobis on Leptocylindrus danicus (40\%), P. cf. divergens (41) and P. crassipes (47) on Lingulodinium polyedrum, or P. huberi on Ditylum brightwellii (59). The energy costs of motility in small, fast-moving protists (swimming at $>100$ body lengths $\mathrm{s}^{-1}$ ) were calculated to be very high ( $>40 \%$ of total energy cost) (Crawford 1992). Therefore, energy loss due to the high swimming speed of $P$. bipes might be the cause of low maximum GGE. Otherwise, the nutritional value of $S$. costatum might be lower than that for $L$. danicus, $L$. polyedrum, or D. brightwellii.

\section{Grazing impact}

Grazing coefficients attributable to Protoperidinium bipes feeding on co-occurring Skeletonema costatum obtained in the present study were 0.001 to $0.034 \mathrm{~h}^{-1}$; 0.1 to $3.4 \%$ of $S$. costatum populations were removed by a $P$. bipes population in $1 \mathrm{~h}$ (Table 1). However, grazing coefficients attributable to Acartia spp. feeding on $S$. costatum were $<0.002 \mathrm{~h}^{-1} ;<0.2 \%$ of $S$. costatum populations were removed by Acartia spp. populations in $1 \mathrm{~h}$. An Acartia spp. density of 33 ind. $\mathrm{l}^{-1}$ would be necessary to produce the same grazing impact $\left(0.034 \mathrm{~h}^{-1}\right)$ on $S$. costatum as $P$. bipes in the coastal waters off Kwangyang. The results of the present study suggest that $P$. bipes may sometimes have considerable grazing impact on the population of cooccurring $S$. costatum, and may be a primary zooplanktonic grazer of this diatom.

Acknowledgements. We thank J. S. Kim, J. Y. Song, T. H. Kim, J. H. Kim, K. A. Seong and M. S. Kim for technical support. This paper was funded by grants from KOSEF (99' RRC, R12-1999-027-12000-0) and KOSEF (R02-2002-000-00012-0).

\section{LITERATURE CITED}

Balkis N (2003) Seasonal variations in the phytoplankton and nutrient dynamics in the neritic water of Büyükçekmece Bay, Sea of Marmara. J Plankton Res 25:703-717

Bralewska JM, Witek Z (1995) Heterotrophic dinoflagellates in the ecosystem of the Gulf of Gdansk. Mar Ecol Prog Ser 117:241-248

Buskey EJ (1997) Behavioral components of feeding selectivity of the heterotrophic dinoflagellate Protoperidinium pellucidum. Mar Ecol Prog Ser 153:77-89

Buskey EJ, Coulter CJ, Brown SL (1994) Feeding, growth and bioluminescence of the heterotrophic dinoflagellate Protoperidinium huberi. Mar Biol 121:373-380

Caroppo C (2000) The contribution of picophytoplankton to community structure in a Mediterranean brackish envi- ronment. J Plankton Res 22:381-397

Conover RJ (1956) Oceanography of Long Island Sound, 1952-1954. VI. Biology of Acartia clausi and A. tonsa. Bull Bingham Oceanogr Coll 15:156-233

Crawford DW (1992) Metabolic cost of motility in planktonic protists: theoretical considerations on size scaling and swimming speeds. Microb Ecol 24:1-10

Deason EE (1980) Grazing of Acartia hudsonica (A. clausi) on Skeletonema costatum in Narragansett Bay (USA): influence of food concentration and temperature. Mar Biol 60: $101-113$

Durbin AG, Durbin EG (1981) Standing stock and estimated production rates of phytoplankton and zooplankton in Narragansett Bay, Rhode Island. Estuaries 4:24-41

Frost BW (1972) Effects of size and concentration of food particles on the feeding behavior of the marine planktonic copepod Calanus pacificus. Limnol Oceanogr 17:805-815

Guillard RRL, Ryther JH (1962) Studies of marine planktonic diatoms. I. Cyclotella nana Hustedt and Detonula confervacea (Cleve) Grun. Can J Microbiol 8:229-239

Hansen PJ (1992) Prey size selection, feeding rates and growth dynamics of heterotrophic dinoflagellates with special emphasis on Gyrodinium spirale. Mar Biol 114: 327-334

Hansen PJ, Bjornsen PK, Hansen BW (1997) Zooplankton

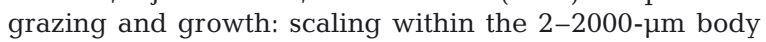
size range. Limnol Oceanogr 42:687-704

Heinbokel JF (1978) Studies on the functional role of tintinnids in the Southern California Bight. I. Grazing and growth rates in laboratory cultures. Mar Biol 47:177-189

Jacobson DM (1987) The ecology and feeding biology of thecate heterotrophic dinoflagellates. PhD dissertation, Woods Hole Oceanographic Institution/Massachusetts Institute of Technology Joint Program, Woods Hole, MA

Jacobson DM, Anderson DM (1986) Thecate heterotrophic dinoflagellates: feeding behavior and mechanisms. J Phycol 22:249-258

Jacobson DM, Anderson DM (1993) Growth and grazing rates of Protoperidinium hirobis Abé, a thecate heterotrophic dinoflagellates. J Plankton Res 15:723-736

Jeong HJ, Latz MI (1994) Growth and grazing rates of the heterotrophic dinoflagellate Protoperidinium spp. on red tide dinoflagellates. Mar Ecol Prog Ser 106:173-185

Jeong HJ, Park JK, Kim JS, Kim ST, Yoon JE, Kim SK, Park YM (2000) The outbreak of red tides in the coastal waters off Kohung, Chonnam, Korea. 3. The temporal and spatial variations in the heterotrophic dinoflagellates and ciliates in 1997. The Sea 5:37-46 (in Korean with English abstract)

Jeong HJ, Yoo YD, Kim JS (2002) Outbreak of red tides in the coastal waters off the southern Saemankeum areas, Jeonbuk, Korea. 2. Temporal and spatial variations in the heterotrophic dinoflagellates and ciliates in the summerfall of 1999. The Sea 7:140-147 (in Korean with English abstract)

Johnson MP, Costello MJ (2002) Local and external components of the summertime plankton community in Lough Hyne, Ireland: a stratified marine inlet. J Plankton Res 24: 1305-1315

Jordana E, Charles F, Gremare A, Amouroux JM, ChretiennotDinet MJ (2001) Food sources, ingestion and absorption in the suspension-feeding polychaete, Ditrupa arietina (O. F. Mueller). J Exp Mar Biol Ecol 266:219-236

Kristiansen S, Farbrot T, Naustvoll LJ (2001) Spring bloom nutrient dynamics in the Oslofjord. Mar Ecol Prog Ser 219: 41-49

Lessard EJ, Swift E (1986) Dinoflagellates from the North 
Atlantic classified as phototrophic or heterotrophic by epifluorescence microscopy. J Plankton Res 8:1209-1215

Levandowsky M, Kaneta PJ (1987) Behaviour in dinoflagellates. In: Taylor FJR (ed) The biology of dinoflagellates. Blackwell Scientific Publications, Oxford, p 360-397

Lovejoy C, Legendre L, Martineau MJ, Bâcle J, von Quillfeldt $\mathrm{CH}$ (2002) Distribution of phytoplankton and other protists in the North Water. Deep-Sea Res 49:5027-5047

Marshall HG, Ranasinghe JA (1989) Phytoplankton distribution along the eastern coast of the USA. VII. Mean cell concentrations and standing crop. Cont Shelf Res 9:153-164

Martin JH (1965) Phytoplankton-zooplankton relationships in Narragansett Bay. Limnol Oceanogr 10:185-191

Menden-Deuer S, Lessard E (2000) Carbon to volume relationships for dinoflagellates, diatoms, and other protist plankton. Limnol Oceanogr 45:569-579

Nakamura Y, Suzuki SY, Hiromi J (1995) Growth and grazing of a naked heterotrophic dinoflagellate, Gyrodinium dominans. Aquat Microb Ecol 9:157-164

Naustvoll LJ (1998) Growth and grazing by the thecate heterotrophic dinoflagellate Diplopsalis lenticula (Diplopsalidaceae, Dinophyceae). Phycologia 37:1-9

Nielsen TG, Lokkegaard B, Richardson K, Pedersen FB, Hansen L (1993) Structure of plankton communities in the Dogger Bank area (North Sea) during a stratified situation. Mar Ecol Prog Ser 95:115-131

Paffenhöfer GA (1976) Continuous and nocturnal feeding of the marine planktonic copepod Calanus helgolandicus. Bull Mar Sci 26:49-58

Peters N (1929) Orts- und Geisselbewegung bei marinen Dinoflagellaten. Arch Protistenkd 67:291-321

Pratt DM (1965) The winter-spring diatom flowering in Narra-

Editorial responsibility: David Caron,

Los Angeles, California, USA gansett Bay. Limnol Oceanogr 10:173-184

Ramaiah N, Furuya K (2002) Seasonal variations in phytoplankton composition and transparent exopolymer particles in a eutrophicated coastal environment. Aquat Microb Ecol 30:69-82

Reid FMH, Lange CB, White MM (1985) Microplankton species assemblages at the Scripps pier from March to November 1983 during the 1982-1984 El Niño event. Bot Mar 28:443-452

Roberts EC, Davidson K, Gilpin LC (2003) Response of temperate microplankton communities to N:Si ratio perturbation. J Plankton Res 12:1485-1495

Skovgaard A, Hansen PJ (2003) Food uptake in the harmful alga Prymnesium parvum mediated by excreted toxins. Limnol Oceanogr 48:1161-1166

Strom SL, Buskey EJ (1993) Feeding, growth, and behavior of the thecate heterotrophic dinoflagellate Oblea rotunda. Limnol Oceanogr 38:965-977

Tiselius P, Kuylenstierna M (1996) Growth and decline of a diatom spring bloom: phytoplankton species composition, formation of marine snow and the role of heterotrophic dinoflagellates. J Plankton Res 18:133-155

Tuschling K, Juterzenka K, Okolodkov YB, Anoshkin A (2000) Composition and distribution of the pelagic and sympagic algal assemblages in the Laptev Sea during autumnal freeze-up. J Plankton Res 22:843-864

Yoo YD, Jeong HJ, Shim JH, Park JY and 5 others (2002) Outbreak of red tides in the coastal waters off the southern Saemankeum areas, Jeonbuk, Korea. 1. Temporal and spatial variations in the phytoplankton community in the summer-fall of 1999. The Sea 7:129-139 (in Korean with English abstract)

Submitted: January 12, 2004; Accepted: April 5, 2004

Proofs received from author(s): June 23, 2004 